Spring 1989

\title{
Democratic Incumbents and the 1984 Presidential Election: A Case Study
}

Kurt Schlichting

Fairfield University, kurt@fairfield.edu

Follow this and additional works at: https://digitalcommons.fairfield.edu/sociologyandanthropologyfacultypubs

Copyright 1989 by University of Chicago Press.

\section{Peer Reviewed}

\section{Repository Citation}

Schlichting, Kurt, "Democratic Incumbents and the 1984 Presidential Election: A Case Study" (1989). Sociology \& Anthropology Faculty Publications. 1.

https://digitalcommons.fairfield.edu/sociologyandanthropology-facultypubs/1

\section{Published Citation}

Schlichting, Kurt. 1989. Democratic Incumbents and the 1984 Presidential Election: A Case Study. Public Opinion Quarterly 53(1):81-90.

This item has been accepted for inclusion in DigitalCommons@Fairfield by an authorized administrator of DigitalCommons@Fairfield. It is brought to you by DigitalCommons@Fairfield with permission from the rightsholder(s) and is protected by copyright and/or related rights. You are free to use this item in any way that is permitted by the copyright and related rights legislation that applies to your use. For other uses, you need to obtain permission from the rights-holder(s) directly, unless additional rights are indicated by a Creative Commons license in the record and/or on the work itself. For more information, please contact digitalcommons@fairfield.edu. 


\title{
DEMOCRATIC INCUMBENTS AND THE I 984 PRESIDENTIAL ELECTION A CASE STUDY
}

KURT C. SCHLICHTING

\begin{abstract}
This article examines the advantages a single Democratic incumbent utilized to win reelection in 1984 despite an overwhelming victory by Ronald Reagan at the top of the ticket in the congressional district. The incumbent won reelection because of two types of ticket splitting: Republican-inclined voters who voted for Republican candidates for president and U.S. Senate and split to vote for the Democratic incumbent for Congress, and Democratic voters who supported Democratic candidates for U.S. Senate and Congress but split to vote for Ronald Reagan for president. Ticket splitting was found to be associated with basic political orientation-weak Republican and independent voters split in favor of the Democratic incumbent and were far less likely to vote a straight ticket for either party. Support for the Democratic incumbent was explained in nonideological terms and was based upon high recognition and favorability, constituent service, voting record, and personal familiarity. For the Republican challenger, who never achieved a high level of recognition (despite significant campaign expenditure), support came almost solely from the most partisan Republican members of the electorate and was based simply upon the party affiliation of the Republican challenger.
\end{abstract}

In 1984, despite one of the most one-sided presidential elections in American history, the Republicans gained only fourteen seats in the House of Representatives and lost two seats in the Senate. Almost all Democratic congressional incumbents who ran for reelection in 1984 won.

The focus of this research is on the reelection of one Democratic incumbent congressman and provides an opportunity to examine at the micro level the advantages that one Democratic incumbent utilized in 1984 to win reelection. The willingness of a significant number of

Kurt c. Schlichting is Associate Professor of Sociology at Fairfield University. The author wishes to thank the Fairfield University Research Committee for support.

Public Opinion Quarterly Volume 53:83-97 (c) 1989 by the American Association for Public Opinion Research Published by The University of Chicago Press / 0033-362X/88/0053-01/\$2.50 
voters to split their ticket proved decisive. The Democratic incumbent won reelection to Congress with $53 \%$ of the votes cast while Walter Mondale, the Democratic presidential candidate, received $36 \%$. The likelihood of ticket splitting was found to be directly correlated with the strength of political affiliation and the high level of recognition and positive evaluation of the incumbent by almost all segments of the electorate. The incumbent congressman was also able to take advantage of the fact that a significant portion of the electorate had decided in favor of the incumbent before September 1984.

Since the 1950s a great deal of attention has been focused on the voting behavior of the American electorate, but the emphasis has been on voting in presidential elections. A recent major study of congressional elections by Goldenberg and Traugott (1984:6) points out the "predominantly presidential focus of virtually all large studies of elections until 1978." It is not until 1978 that the National Election Study (NES) conducted by the University of Michigan substituted congressional districts for counties as primary sampling units and began to include questions specific to the congressional elections.

The major limitation of the NES, the primary source for survey data on congressional elections, is that few interviews are conducted in any one congressional district. The Goldenberg and Traugott analysis focuses on types of congressional races: open seats, incumbent seats, incumbent-sure winners, incumbent-vulnerables, and not on any one congressional district. The authors analyze 86 contested races among the 108 congressional districts in the NES sample (1984). The survey data is drawn from the 1978 NES and consists of 1,843 interviews, an average of 21 interviews per district in the contested districts $(N=86)$.

The present study examines survey data from a single congressional district for the 1984 presidential election. The congressional district analyzed is located in a large midwestern state and consists of urban, suburban, and rural areas. Its other demographic characteristics mirror those of the state as a whole. The congressional district is one which was identified by both parties as "marginal" ("vulnerable" in Goldenberg and Traugott terminology) in 1984. The incumbent Democrat faced a strong challenge from a well-financed Republican. The Republican challenger spent over $\$ 450,000$, while the incumbent's campaign expenditures exceeded $\$ 555,000$.

\section{Method}

The primary data for this study comes from a postelection survey conducted one week after the presidential election in 1984. Interviewing took place from 12 to 15 November. The postelection survey in- 
cluded 600 completed telephone interviews and consisted of a stratified systematic sample. The cities and townships in the congressional district were divided into four areas, and within each a systematic sample was selected from computerized lists of all registered voters. Each of the four areas in the district was sampled in proportion to its contribution to the total votes cast in 1984.

Seven percent of the respondents indicated that they had not voted in the 1984 election; they were asked their vote intention and then the basic demographic questions. An additional $7 \%$ indicated that they could not remember for whom they had voted in the congressional election and were also not included in the analysis.

The analysis also examines data from a series of six preelection polls conducted in the congressional district. The first took place in February of 1984 and the last one week before the November 1984 election. Each of the preelection polls consisted of 600 completed interviews. The samples were selected systematically from a computerized list of all registered voters in the district. Townships in the district were sampled in proportion to their contribution to the 1982 total vote.

\section{Ticket Splitting}

For Democratic House incumbents to have enjoyed such electoral success in 1984 despite President Reagan's overwhelming Republican victory at the top of the ballot meant a great deal of ticket splitting occurred. A sizable portion of the electorate in districts where Democratic incumbents won reelection voted for Reagan for president and for the Democratic incumbent in the race for the U.S. Congress. Ornstein (1985:12) argues that in 1984 the Republicans attempted to "run a comprehensive party effort" which tried to "coordinate activities to a considerable degree and ran an expensive and party-based campaign to win seats in Congress." The coordinated effort was not successful.

The postelection survey asked respondents for whom they voted in the races for president, U.S. Senate, and U.S. Congress. Respondents can be divided into two categories: voters who were Democratically inclined-voting for two Democratic candidates for the three officesand Republican-inclined voters who voted for two out of three Republican candidates.

Within each of these two major categories, almost equal thirds of the electorate voted either straight Republican or straight Democratic. Among Democratic-inclined voters, few split their tickets to vote for either the Republican Senate or House challengers. For Republicaninclined voters, less than $7 \%$ defected to vote for the Democratic Sen- 
Table I. Ticket Splitting, Postelection Survey, November 1984

\begin{tabular}{|c|c|c|c|c|}
\hline & President & Senate & Congress & Percent \\
\hline \multicolumn{5}{|l|}{ Democratic inclined voters } \\
\hline Straight Democrat & $\mathrm{D}$ & $\mathrm{D}$ & $\mathrm{D}$ & 28.6 \\
\hline Split-Democrat for Reagan & $\mathrm{R}$ & $\mathrm{D}$ & $\mathrm{D}$ & 17.5 \\
\hline Split-Democrat for & & & $\mathrm{D}$ & 8 \\
\hline $\begin{array}{l}\text { Republican Senate candidate } \\
\text { Split-Democrat for }\end{array}$ & D & $\mathrm{R}$ & & .8 \\
\hline $\begin{array}{l}\text { Split-Democrat for } \\
\text { Republican House challenger }\end{array}$ & $\mathrm{D}$ & $\mathrm{D}$ & $\mathrm{R}$ & .8 \\
\hline \multicolumn{5}{|l|}{ Republican inclined voters } \\
\hline Straight Republican & $\mathrm{R}$ & $\mathbf{R}$ & $\mathbf{R}$ & 31.5 \\
\hline Split-Republican for Mondale & $\mathrm{D}$ & $\mathbf{R}$ & $\mathbf{R}$ & .7 \\
\hline $\begin{array}{l}\text { Split-Republican for } \\
\text { Democrat Senate candidate }\end{array}$ & $\mathbf{R}$ & D & $\mathrm{R}$ & 6.6 \\
\hline $\begin{array}{l}\text { Split-Republican for } \\
\text { Democrat House incumbent }\end{array}$ & $\mathrm{R}$ & $\mathrm{R}$ & $\mathrm{D}$ & 13.6 \\
\hline Total $N$ & & & & 487 \\
\hline
\end{tabular}

ate candidate, and almost none voted for the Democratic presidential candidate (see Table 1).

The electoral success of this Democratic incumbent in 1984 was based upon two types of ticket splitting. The first consisted of voters who voted for Democratic candidates on the congressional ticket and for Ronald Reagan for president (17.5\%). In this group, the fundamental orientation was to support Democratic candidates; however, the personal appeal of Ronald Reagan overcame basic party orientation. The first survey in February found that $73 \%$ of the electorate had a positive evaluation of Ronald Reagan and $62 \%$ rated the job he was doing as president as "excellent" or "pretty good." His high personal favorability and job rating did not change over the course of the entire campaign.

The second type of ticket splitters (13.6\%) voted for Republican candidates for president and Senate and then defected and voted for the Democratic incumbent for Congress. Here, the personal popularity and appeal of the incumbent congressmen countered a fundamental Republican party orientation.

The probability of ticket splitting is directly correlated with basic political orientation. Those in the electorate with strong partisan orientations are the least likely to split. However, even among "strong" Republicans, $12 \%$ indicated they had voted for the Democratic incumbent at the congressional level (Table 2). The converse was not the 
Table 2. Ticket Splitting and Political Orientation, Postelection Survey, November 1984

\begin{tabular}{lccccccc}
\hline & $\begin{array}{c}\text { Strong } \\
\text { Dem }\end{array}$ & $\begin{array}{c}\text { Weak } \\
\text { Dem }\end{array}$ & $\begin{array}{c}\text { Ind } \\
\text { Lean } \\
\text { Dem }\end{array}$ & Ind & $\begin{array}{c}\text { Lean } \\
\text { Rep }\end{array}$ & $\begin{array}{c}\text { Weak } \\
\text { Rep }\end{array}$ & $\begin{array}{c}\text { Strong } \\
\text { Rep }\end{array}$ \\
\hline $\begin{array}{l}\text { Straight Dem } \\
\text { Split-Dem for }\end{array}$ & $94 \%$ & $60 \%$ & $72 \%$ & $19 \%$ & $5 \%$ & $3 \%$ & $2 \%$ \\
$\quad \begin{array}{l}\text { Reagan } \\
\text { Split-Rep for }\end{array}$ & 2 & 29 & 17 & 31 & 22 & 16 & 9 \\
$\begin{array}{l}\text { Dem Senate } \\
\text { Split-Rep for }\end{array}$ & & 2 & 6 & 3 & 8 & 10 & 12 \\
$\begin{array}{l}\text { Dem House } \\
\text { incumbent }\end{array}$ & 2 & 4 & 4 & 22 & 19 & 22 & 12 \\
Straight Rep & 2 & 4 & 2 & 24 & 45 & 49 & 66 \\
$\quad$ Total $N$ & 50 & 44 & 60 & 89 & 112 & 100 & 67 \\
\hline
\end{tabular}

Question: Generally speaking, do you think of yourself as a Republican, a Democrat, an independent, or what?

(If Democrat:) Would you call yourself a strong Democrat or a not very strong Democrat?

(If Republican:) Would you call yourself a strong Republican or a not very strong Republican?

(If independent:) Do you think of yourself as closer to the Republican or Democratic party?

case; few "strong" Democrats voted for the Republican congressional challenger. This illustrates one of the advantages an incumbent enjoys: the appeal of the incumbent was such that it was even capable of pulling away some of the strongest partisans of the other party.

The incumbent was more successful among voters whose Republican partisan orientation was more moderate-weak Republicans and independents leaning Republican. With these two groups, the proportion voting a straight party ticket declined to less than $50 \%$. Almost one-fifth of each of these categories of voters split their tickets specifically in favor of the Democratic incumbent. This illustrates the ability of the Democratic incumbent to reach across basic party orientation. As Ornstein (1985:13) states, the 1984 voting "reflects less the ineptitude of the challenger than the impressive abilities of Democratic House incumbents to build powerful niches to withstand strong adverse tides." Part of that niche consisted of a successful appeal to those who had less than the strongest partisan ties to the Republican party and its candidate. 
TICKET SPLITTING AND CANDIDATE DECISION TIME

The time at which the choice for Congress was made was a factor in the incumbent's reelection, and this also varied according to the type of ticket cast. Among those who voted a straight Democratic ticket, $61 \%$ indicated they had decided to vote for the Democratic incumbent congressional candidate before September 1984 (Table 3). In addition, 88\% of this group responded that they had "never considered voting for" the Republican challenger. This segment of the electorate represented a solid base the Democratic incumbent used to secure reelection.

The two major groups of ticket splitters, Democratic voters who split and voted for Reagan for president $(17.5 \%)$ and Republican voters who voted for the Democratic incumbent for Congress $(13.6 \%)$, were divided between those who had decided to vote for the Democratic incumbent prior to September (35\% and $39 \%$ respectively) and those who decided their vote within a week of the election $(37 \%$ and $33 \%$ ). Both groups of ticket splitters contained significant numbers of voters who decided to vote for the Democratic incumbent before the political season began.

REASONS FOR TICKET SPLITTING

Ticket splitters were asked directly why they voted for the Republican candidate for president and the Democratic candidate for Congress.

Table 3. Congressional Vote Decision Time and Ticket Splitting. Postelection Survey, November 1984

\begin{tabular}{lcccc}
\hline & $\begin{array}{c}\text { Straight } \\
\text { Democrat }\end{array}$ & $\begin{array}{c}\text { Split_Dem } \\
\text { for Reagan }\end{array}$ & $\begin{array}{c}\text { Split-Rep } \\
\text { for Dem House } \\
\text { Incumbent }\end{array}$ & $\begin{array}{c}\text { Straight } \\
\text { Republican }\end{array}$ \\
\hline Decision Time & $9 \%$ & $18 \%$ & $18 \%$ & $25 \%$ \\
Right near & 6 & 18 & 15 & 9 \\
Week before & 10 & 15 & 18 & 18 \\
October & 9 & 9 & 6 & 6 \\
September & 61 & 35 & 39 & 33 \\
Before September & 5 & 5 & 4 & 9 \\
Can't remember/ & 139 & 85 & 66 & 153 \\
$\quad$ don't know & & & & \\
\hline Total $N$ & & &
\end{tabular}

QUESTION: When did you finally decide to vote for (Republican/Democrat)right near election day, the week before, sometime in October, sometime in September or before that? 
The most common responses were that they "vote for the individual" $(40 \%)$ or that they "always split their ticket" (21\%) (Table 4). Both of these responses suggest an absence of partisan loyalty among this segment of the electorate.

A second interpretation of those responses which suggest consistent ticket splitting from election to election is that the race for the two offices, president and Congress, are divorced from one another. Ladd has argued that "presidential and congressional voting are two distinct systems"; he further explains "the two-tier electoral system as Americans' liking for separation of powers and checks and balances . . . by ordaining divided party control"' (1985:3).

Many responded to the question posed by focusing their explanation for ticket splitting on the congressional race. They felt no need to explain their vote for Reagan; rather, the need was to explain their simultaneous vote for the Democratic incumbent. A significant portion (19\%) offered their favorable evaluation of the incumbent, personal acquaintance with the congressman or his office, or mentioned specific district services as reasons for their split voting for the congressional incumbent.

\section{INCUMBENT RECOGNITION}

One of the most powerful advantages that incumbent congressmen enjoy is a high level of recognition. Hinckley and others have argued

Table 4. Reasons for Ticket Splitting, Postelection Survey, November 1984

Reason

Always vote for individual

Always split ticket

$40 \%$

For Democratic incumbent

21

For Ronald Reagan

19

Keep balance in Washington

5

Against Mondale

7

Miscellaneous

6

2

Total $N$

141

Question: You voted it seems for Republican Ronald Reagan and Democrat (name Democratic incumbent). Most people in (state) this year voted for all Democrats or all Republicans. Why did you decide to split your ticket and vote for Republican Ronald Reagan and Democrat (name)? 
that incumbents win reelection so often because they are well known and their opponents are comparatively unknown. "For a large number of House voters, essentially no choice is provided, one candidate is known the opponent is not. . . House incumbents enjoy a strong margin of support, but they also enjoy the boon of fairly invisible challengers" (Hinckley, 1980:51).

The complicating factor for the challenger in congressional elections is the fact that incumbent congressmen are evaluated in very positive terms by the constituents of their districts.

The Democratic congressman in the congressional district being examined enjoyed both advantages described above. When the first poll was conducted in February 1984, $78 \%$ of the electorate could provide an evaluation, while only $9 \%$ had never heard of the Democratic incumbent. Most of the voters who provided an evaluation gave the incumbent a positive rating ( $58 \%$ ), while only $19 \%$ indicated a negative evaluation. This positive evaluation remained stable throughout the campaign.

The position of the Republican challenger was much more disadvantageous. In February 1984 he was virtually unknown, and even with a substantial campaign effort on the part of the challenger, the last poll prior to election day found that $17 \%$ of the electorate had never heard of the Republican challenger, and a significant proportion of the electorate $(42 \%)$ had not formed either a positive or negative evaluation of the candidate. The Republican challenger failed to reach the threshold of recognition necessary to engage the electorate sufficiently to make this particular congressional election a true contest between two candidates.

Further, the evaluation of the Democratic incumbent varied to a significant degree with the political orientation of the respondent. The negative evaluation of the Democratic incumbent was concentrated among the partisan Republicans ("strong" Republicans). When the two other Republican categories are examined ("weak Republican" and "Independent-lean Republican"), favorability changes dramatically. Only $34 \%$ of the strong Republicans provided a positive evaluation of the Democratic incumbent, but a majority of both the weak Republicans and the independents leaning Republican did. A majority of both of these groups reported voting for the Democratic incumbent, despite the fact that they described their fundamental political orientation as Republican. The partisan ties of these groups were not strong enough to counter their positive evaluation of the Democratic incumbent (see Table 5).

Goldberg and Traugott (1984:136) have argued that a voter's choice of candidates is "a composite of recognition and evaluation filtered through a voter's partisan political identification." In this congres- 
Table 5. Recognition and Favorability by Political Orientation, Democratic Incumbent, Postelection Survey, November 1984

\begin{tabular}{lccccccc}
\hline & $\begin{array}{c}\text { Strong } \\
\text { Dem }\end{array}$ & $\begin{array}{l}\text { Weak } \\
\text { Dem }\end{array}$ & $\begin{array}{c}\text { Ind } \\
\text { Lean } \\
\text { Dem }\end{array}$ & $\begin{array}{c}\text { Ind } \\
\text { Ind }\end{array}$ & $\begin{array}{c}\text { Lean } \\
\text { Rep }\end{array}$ & $\begin{array}{c}\text { Weak } \\
\text { Rep }\end{array}$ & $\begin{array}{c}\text { Strong } \\
\text { Rep }\end{array}$ \\
\hline Very favorable & $26 \%$ & $23 \%$ & $21 \%$ & $9 \%$ & $8 \%$ & $4 \%$ & $12 \%$ \\
Favorable & 56 & 66 & 62 & 58 & 44 & 56 & 30 \\
Unfavorable & 2 & 2 & 8 & 10 & 17 & 18 & 31 \\
Very unfavorable & - & - & 2 & 3 & 5 & 4 & 4 \\
No opinion & 11 & 9 & 7 & 18 & 24 & 18 & 27 \\
Never heard & 6 & - & - & 3 & 3 & 1 & 3 \\
$\quad$ Total $N$ & 50 & 44 & 67 & 89 & 112 & 100 & 67 \\
\hline
\end{tabular}

QUEsTION: Now, I am going to read you a list of political figures and I would like you to tell me whether in general you have a very favorable, favorable, unfavorable or very unfavorable opinion of each one. If you have no opinion or have never heard of someone, please say so.

sional election, the partisan identification of only the "strong Republicans" was sufficient enough to overcome the recognition and positive evaluation of the Democratic incumbent.

\section{INCUMBENT SUPPORT AND CANDIDATE DECISION TIME}

The time dimension in the decision-making process was another factor in the incumbent's favor. There was a significant difference between those who voted for the Democratic incumbent and those who voted for the Republican challenger in terms of when they made their choice between candidates. Slightly over half of those who voted for the Democratic incumbent indicated that they had decided to vote for the incumbent before September 1984 (Table 6). The conventional wisdom is that American political campaigns do not really begin until Labor Day, the first week in September. If that is the case, then even before the congressional campaign had begun, the Democratic incumbent had already obtained half of his eventual electoral support. The corresponding figure for the Republican challenger was $32 \%$.

\section{INCUMBENT SUPPORT AND OPPOSITION}

The postelection survey included two open-ended questions which asked respondents why they voted for their candidate for Congress and 
Table 6. Vote Decision Time and Congressional Candidate Preference, Postelection Survey, November 1984

\begin{tabular}{lcc}
\hline Decision Time & $\begin{array}{c}\text { Republican } \\
\text { Challenger }\end{array}$ & $\begin{array}{c}\text { Democrat } \\
\text { Incumbent }\end{array}$ \\
\hline Right near & $25 \%$ & $14 \%$ \\
Week before & 14 & 11 \\
October & 18 & 12 \\
September & 7 & 8 \\
Before September & 32 & 50 \\
$\quad$ Total $N$ & 228 & 314 \\
\hline
\end{tabular}

Question: When did you finally decide to vote for (Republican/Democrat)-right near election day, the week before, sometime in October, sometime in September or before that?

why they voted against the other candidate. The two factors cited most often as reasons for voting for the incumbent included constituent service $(25 \%)$ and his record on various issues $(26 \%)$ (see Table 7 ). In previous studies, constituent service had been identified as a most important reason for supporting a House incumbent at election time (Parker, 1981). This is an advantage that only an incumbent can enjoy.

Table 7. Reasons for Voting For and Against the Democratic Incumbent, Postelection Survey, November 1984

\begin{tabular}{lcc}
\hline & Vote For & Vote Against \\
\hline Constituent services & $25 \%$ & - \\
Record/issues & 26 & $29 \%$ \\
Personal qualities & 12 & 24 \\
Experience & 12 & 8 \\
Party & 10 & 30 \\
Campaign activity & 6 & 4 \\
Anti-Reagan & - & 6 \\
Miscellaneous & 9 & 157 \\
\multicolumn{1}{c}{ Total $N$} & 288 &
\end{tabular}

QUESTIONS: What was the main reason you voted for Democrat (name)/Republican (name)? What was the main reason you did not vote for Democrat (name)/Republican (name)? 
Constituent service is at the heart of the election success of House incumbents and helps to explain the apparent contradiction between the general negative evaluation of Congress by the American public on the one hand, and the high positive evaluation of individual members of Congress by their constituents. The image of the services provided by the incumbent was entirely positive. Not one of the respondents who voted against the incumbent indicated that they did so because of poor or nonexistent constituent service.

Political affiliation was not identified as an important reason in voting for a Democratic incumbent; rather, the emphasis was placed on service, voting record, and personal favorability. It was not surprising that many Democratic incumbents played down their party affiliation in the 1984 election. With some incumbents, it was difficult to find the word "Democrat" anywhere in their campaign literature or media advertising.

The reasons for voting against the incumbent focused on his record, negative personal qualities, and party affiliation. Party was not an important reason for voting for the Democratic incumbent but remained a reason for voting against him.

The comparative importance of the various reasons for voting for the Democratic incumbent varied by category of voter. For the two groups of ticket splitters, party declined sharply in salience. For the Democratically inclined voters who split to vote for Ronald Reagan, the most important reason for supporting the Democratic incumbent candidate for Congress was his voting record (32\%). With this group, support was based upon an ideological affinity with the positions taken by the congressmen while in office. Constituent service (22\%) was of less importance.

Individuals who voted Republican for both president and Senate and defected at the House level to support the Democratic incumbent identified service to the district as paramount in importance. Their defection to the Democratic incumbent is explained in nonideological terms. Constituent service provided Republican-oriented voters with a rationale for their defection.

For the Republican challenger, support was based primarily upon party (38\%) and opposition, on a personal basis, to the Democratic incumbent (22\%) (see Table 8). Issues played a very small part in either the support for or the opposition to the Republican challenger. The reason most often cited for not voting for the Republican challenger was this lack of recognition (41\%). As the earlier data pointed out, the Republican candidate never achieved districtwide recognition of over $51 \%$. It is also significant that "lack of experience" was mentioned by $12 \%$ of the respondents as a reason for not voting for the challenger to the Democratic House incumbent (Table 8). "Lack of experience" for 
Table 8. Reasons for Voting For and Against the Republican Challenger, Postelection Survey, November 1984

\begin{tabular}{lcc}
\hline & Vote For & Vote Against \\
\hline Party & $38 \%$ & $11 \%$ \\
Personal qualities & 20 & 22 \\
Lack of experience & - & 12 \\
Issues & 10 & 8 \\
Lack of recognition & - & 41 \\
Support Reagan in Congress & 7 & - \\
Anti-Democratic incumbent & 22 & 6 \\
Miscellaneous & 3 & 219 \\
$\quad$ Total $N$ & 190 &
\end{tabular}

Questions: What was the main reason you voted for Democrat (name)/Republican (name)? What was the main reason you did not vote for Democrat (name)/Republican (name)?

the challenger is the reverse side of incumbency. Incumbents of both parties can and do emphasize their "experience" in reelection campaigns. It is difficult for the challenger to counter this argument because, except on rare occasions, he or she does not have legislative experience in Washington.

Very few of those who voted for the Republican congressional candidate identified support for Ronald Reagan as the primary reason for doing so. As Ornstein (1985) argues, the Republicans in 1984 were not successful in linking the reelection of an extremely popular Republican president with voting for Republican candidates for Congress who would in turn support the president. This theme proved to have very little appeal in this congressional district.

The straight Republican voters who provided the Republican challenger with most of his electoral support offer party as the primary reason for their vote choice. A significant number of straight Republican voters (48\%) could not provide an opinion of the Republican candidate or had never heard of him. Therefore, the only reason for voting for the challenger was that he was the candidate of the Republican party. The second most important factor with these straight ticket voters was their negative attitude toward the Democratic incumbent which was phrased in very individual terms and not couched in opposition to the incumbent's party or record on particular issues. They represented the hard-core opposition to the incumbent evident in the first poll in February 1984. 
In an election with a relatively unknown Republican challenger to a popular Democratic candidate, the only viable reasons for not voting for the incumbent were strong partisan Republican loyalties or personal animosity toward the Democratic incumbent. The combination of these two factors was not enough to unseat the current officeholder.

\section{Multivariate Analysis}

In order to assess the relationship between vote for the Democratic incumbent and the various independent variables examined, a logistic regression analysis was performed.

Favorability rating and political orientation were the two independent variables with the highest coefficients relative to their standard errors. The high recognition of the incumbent combined with positive evaluations were clearly factors which explain votes for the incumbent. The first two variables support Goldenberg and Traugott's hypothesis that vote choice is a composite of recognition and favorability filtered through a voter's political identification (see Table 9).

Personal contact, the third significant variable, is an additional com-

Table 9. Logistic Regression Analysis: Dependent Variable = Vote for Democratic Incumbent

\begin{tabular}{lccc}
$\begin{array}{l}\text { Independent } \\
\text { Variable }\end{array}$ & $\begin{array}{c}\text { Regression } \\
\text { Coefficient }\end{array}$ & $\begin{array}{c}\text { Standard } \\
\text { Error }\end{array}$ & Coeff./S.E. \\
\hline Favorability (incumbent) & -.74 & .11 & -6.67 \\
Party & -.28 & .05 & -5.71 \\
Time & -.01 & .05 & .11 \\
Record & 4.65 & 4.93 & .94 \\
Constituent services & 4.47 & 5.69 & .78 \\
Personal contact & 1.37 & .53 & 2.61 \\
Constant & 7.98 & & \\
Degrees of freedom & 460 & &
\end{tabular}

CoDing: vote for incumbent: 1 = incumbent, $0=$ not for incumbent; favorability: $1=$ very favorable, $2=$ favorable, $3=$ no opinion, $4=$ unfavorable, $5=$ very unfavorable; party: 1 = strong Democrat, 2 = weak Democrat, 3 = independent-lean Democrat, $4=$ independent, $5=$ independent-lean Republican, $6=$ weak Republican, $7=$ strong Republican; time: $1=$ right near, $2=$ week before, $3=$ October, $4=$ September, $5=$ before September; record: $1=$ mention record, $0=$ not mention; constituent service: 1 = mention constituent service, $0=$ not mention; personal contact: 1 = mention contact with incumbent, $0=$ not mention contact. 
ponent of incumbent strength. Recognition for this segment of the electorate is more than simply knowing the name of their incumbent representative. Respondents indicated that they had personally met the incumbent, dealt with the incumbent's office, or had family members and friends who had. This form of personal interaction builds and sustains the overall favorability of the incumbent.

The logistic regression analysis supports the hypothesis that voting for an incumbent is primarily associated with recognition, party identification, and positive personal interaction. Incumbents with high personal recognition and favorability are formidable regardless of the presidential candidates at the top of the ticket.

\section{Summary}

The incumbent won reelection because major segments of the electorate split their tickets. Ticket splitting was correlated with basic political orientation. Weak Republican and independent voters split in favor of the Democratic incumbent and were far less likely to vote a straight ticket for either party.

The postelection poll found that $50 \%$ of those who voted for the Democratic incumbent indicated they had decided to support their candidate before September. This provided the incumbent with a sizable base which was secured before the most crucial phase of the campaign for Congress began in September.

Support for the Democratic incumbent was explained in nonparty terms: constituent service, voting record, and position on various issues. The first two sources of support are usually only available to an incumbent. Party was not offered as a reason for voting for the incumbent, but it was the most significant factor used to explain voting for the Republican challenger. With a Republican candidate who remained unknown to a large part of the electorate, the major sources of support were party affiliation and personal animosity toward the Democratic incumbent. The combination of these two factors were not sufficient to defeat the current officeholder, despite the success of Ronald Reagan at the top of the Republican ticket.

\section{References}

Goldenberg, Edie N., and Michael W. Traugott (1984)

Campaigning for Congress. Washington: Congressional Quarterly.

Hinckley, Barbara (1980)

Congressional Elections. Washington: Congressional Quarterly. 
Ladd, Everett (1985)

"As the realignment turns: A drama in many acts." Public Opinion 7(6):2-7. Ornstein, Norman J. (1985)

"Changing Congress's course: Republicans still in the wings." Public Opinion $7(6): 12-14$.

Parker, Glenn (1981)

"Incumbent popularity and electoral success." Pp. 249-279 in Louis Maisel and Joseph Cooper (eds.), Sage Electoral Studies Yearbook, vol. 6. Beverly Hills, CA:

Sage. 